\title{
The Tropical Gothic and Beyond: El Grupo de Cali's Legacies for Contemporary Latin American Literature, Cinema, and Culture
}

\section{Felipe Gómez G.}

Carnegie Mellon University, USA

\begin{abstract}
The creation and development of a tropical gothic is arguably the most important legacy of El Grupo de Cali, an interdisciplinary collective led by writer and film critic Andrés Caicedo Estela, and filmmakers Carlos Mayolo and Luis Ospina, during the 1970s in Colombia. In El Grupo's tropical gothic, the conventions of the literary and cinematic gothic undergo a process of transculturation and tropicalization. With this transformation, Caicedo, Mayolo and Ospina postulate a dark reality that is urban and violent, and in which youth have protagonist roles both as agents and victims of violence. The revival of the monster within this tropical gothic reveals itself as intrinsically linked not only to the influence of cinematic tropes such as Hollywood B-series vampire films, but also to the connections between local myths and legends and forms of structural violence rooted in socioeconomic, political, racial and sexual oppression. Beyond the development of a tropical gothic aesthetic, the innovations of Caicedo's literary writing include the insistence in locating youthful characters in urban, countercultural scenarios defined by elements of popular culture such as film, popular music, or drugs. These characteristics effectively locate his writings on the flip side of magical realism and act as complements to the Grupo's tropical gothic in their efforts to narrate the experience of the modern tropical Latin American city.
\end{abstract}

Keywords: tropical gothic; Grupo de Cali; Caicedo Estela, Andrés; Mayolo, Carlos; Ospina, Luis. 

interdisciplinary collective of young writers, artists, and intellectuals who gathered around the Cine Club de Cali and its magazine Ojo al cine during the 1970s in Colombia. When I first began my own research into this group in the 1990s (Gómez, 2004a; 2004b; Gómez Gutiérrez, 2007), few people outside of Colombia had heard of them. Since that time, the three most visible leaders of this group, writer and film critic Andrés Caicedo Estela, and filmmakers Carlos Mayolo and Luis Ospina, have garnered momentum in terms of critical reception, leading to the publication of edited volumes, dozens of articles in Colombian and international journals and magazines, new or translated editions of their works intended for broader audiences, as well as to significant local and international awards and recognitions. ${ }^{1}$ Given the undeniable currency and value acquired by the Grupo over this period, a close consideration of their foundational contributions is essential in any engagement with the gothic in the Latin American tropics. ${ }^{2}$

\footnotetext{
1 See for instance the volumes La estela de Caicedo (Duchesne Winter \& Gómez Gutiérrez, 2009), Oiga/Vea: sonidos e imágenes de Luis Ospina (Chavarro, Arbeláez \& Ospina, 2011), or the two chapters on Mayolo's and Ospina's films included in Horrofilmico (Díaz-Zambrana \& Tomé, 2012); articles in Cahiers du Cinema and Revista de Estudios Colombianos; and the editions of works by Caicedo published by Norma and Alfaguara, and of DVD sets of films by Ospina and Mayolo published by the Fundación Patrimonio Fílmico de Colombia and Proimágenes under the curation of Juana Suárez and Diego Rojas. Furthermore, translations of Caicedo's short stories, novel, and film criticism have been published recently into French by Belfond (Caicedo Estela, 2012; 2013), and into English by Penguin Classics (Caicedo Estela, 2014). Meanwhile, Ospina's film on writer Fernando Vallejo was awarded Best Documentary at the prestigious Radio Francia Internacional Festival in Toulouse (France) in 2004, and the director was honored with the Chevalier de l'Ordre des Arts et des Lettres (Knight of the Order of Arts and Letters) by the French Minister of Culture in 2018. Both Ospina and Mayolo received the "Premio a toda una vida dedicada al cine" (Lifetime Achievement Award) from the Colombian government's Ministerio de Cultura in 2010 and 2006, respectively, for their trajectory and fundamental contribution to Colombian cinema.

${ }^{2}$ Gothic, magical realism, and the fantastic are all terms invoked when speaking of the cultural production of Colombia and Latin America in the $20^{\text {th }}$ century. Even Caicedo and Mayolo talk about the fantastic when describing ideas that we now ascribe as part of the tropical gothic. Establishing clear distinctions between these terms in Latin America is the subject of an ongoing debate that can be traced back to arguments made by Ángel Flores, Luis Leal, and Emir Rodríguez Monegal in the 1950s, 60s, and 70s. Regarding these terms and the debate, see, for instance: Planells (1988), Gutierrez-Mouat (2005), Negroni (2009), and the introduction to Casanova-Vizcaíno \& Ordiz (2018). Settling that debate exceeds the purpose of this article, but suffice it to say that my understanding of the gothic emphasizes an atmosphere-though there may not always be ancient, haunted mansions, imperiled heroines, sinister masculine figures, and unexplained events, the gothic includes characters who oscillate in the ambiguity between good and evil and are enclosed in spaces defined by "the gloomy, the mysterious, and the ruined" (Hopkins, 2005), symbolic expression of established fears stemming from changes in the social, economic, and political order: "The gothic is an imagination of resistance and conservation, of barricading in a foregone order, of nostalgia of the past" (Florez \& Zuluaga, 2015). Implicit in the conceptualization of its tropicalization is the gothic's attempts, but ultimate failure, at fending off those extraneous, foreign,
} 
Over the past two decades various critics have called attention to how the consolidation of the Grupo's pioneering work in the creation of a literary and cinematic "tropical gothic" enables us to look retroactively at Latin American cultural production in a different light, both historically and geographically (Berdet, 2016, p. 48; Duchesne Winter \& Gómez Gutiérrez, 2009; Eljaiek-Rodríguez, 2010; 2012; 2018; Gómez, 2004a; 2004b; Gómez Gutiérrez, 2007; Paranaguá, 1996; Suárez, 2009; 2014a; 2014b; among others). Indeed, to see and read of cannibals, vampires, and zombies roaming the homes, streets, and haciendas in the Colombian city of Cali in the 1970s allows us to visualize parts of contemporary Latin America as tropical gothic spaces, and their cultural production as narratives permanently being re/co-written in dialogue with a continuously-present tradition (Gómez Gutiérrez \& De la Vega-Hurtado, 2009; Gómez Gutiérrez, 2012; 2014). Under the current resurgence of the Gothic in academic and popular cultures, these decades of research have joined a larger body of criticism allowing for new readings of the Gothic in Latin America. Rather than proposing a mere translation or transposition of elements and conventions, the new readings invite us to envisage and delve into transformations arising from the Gothic's intermingling with local questions of past and present colonialism, violence, or social inequality (Casanova-Vizcaíno \& Ordiz, 2018; Edwards \& Vasconcelos, 2016).

In this article I want to highlight ways in which the body of work created by the Grupo explores tropes, liminalities, and hidden histories of colonialism to develop a tropical rewriting of the gothic. These culturally-specific, local formulations resonate with Colombian and Latin American social, political, and economic transformations. Bearing in mind the prolific nature of Caicedo's writing - as well as the foundational role he held within the Grupo in the development of the themes, styles, and aesthetics of a tropical variation of the gothic, and the inspiration he transmitted to his fellow partners both while alive and after his premature death - this paper focuses broadly on his texts, while also discussing works by Ospina and Mayolo that contribute directly to the analytical category at stake. Finally, I consider some of Caicedo's additional legacies beyond the tropical gothic for contemporary Latin American literature, cinema, and culture.

\section{Andrés Caicedo and El Grupo de Cali: Tropicalizing the Gothic}

I would argue that the Grupo's most important legacy is the creation and development of a "gótico tropical" (tropical gothic) amidst the Colombian sociopolitical and cultural

strange, or uncanny elements, whereas magical realism embraces the occurrence of the extraordinary as an integral part of its everyday reality. 
context of the 1960s and 70s. When I use this key concept with regards to their work, I refer to an aesthetic privileging of processes of transculturation and tropicalization in an active rereading of the conventions and tropes of the literary and cinematic gothic and neo-gothic (Gómez, 2004a; 2004b; Gómez Gutiérrez, 2007). ${ }^{3}$ Following ideas proposed by Frances Aparicio and Susana Chávez-Silverman (1997), I speak of "tropicalizations" in intimate relation with the concept of "transculturation" developed by Cuban anthropologist Fernando Ortiz ([1940] 1987) in terms of "the dynamic, mutual influence that a subordinate and a dominant culture effect on each other" (Aparicio \& ChávezSilverman, 1997, p. 1). "To tropicalize," Aparicio and Chávez-Silverman offer, is "to trope, to imbue a particular space, geography, group, or nation, with a particular set of traits, images, and values" (1997, p. 8). A hegemonic type of tropicalization happens in which "dominant (Anglo and European) cultures trope Latin American and U.S. Latino/a identities and cultures" (Aparicio \& Chávez-Silverman, 1997, p. 1). All the while, in the "third spaces" (Bhabha, 1984) and "contact zones" (Pratt, 1991) of colonial encounters, a different, more radical sort of tropicalization also emerges, transforming the dominant culture's stereotypes into "weapons of resistance" (Aparicio \& Chávez-Silverman, 1997, p. 12) through a process of "transculturation from below" (Beverley, 1994, p. 283) or from the margins.

In the work by the Grupo I accordingly signal the double-edged process of topicalization by which the young creators locate themselves in their own tropical, urban setting and proceed to both cannibalize, and let themselves be cannibalized by, the Gothic. Treating its canonic grammar as Shakespeare's Caliban would treat Prospero's colonizing language in The Tempest, ${ }^{5}$ the Grupo curses and spits the Gothic into the parameters of their localized contemporary reality even as they simultaneously digest its codes. In this process, they transgress and re-cast a local language of horror made up from representations of monstrosity already present in a wide variety of locally-sourced documents ranging from colonial chronicles and official historiographies, to journalistic accounts and mediatic images, to legends and popular myths.

\footnotetext{
${ }^{3}$ For discussions of the origins and characteristics of the literary and cinematic Gothic, see for instance: Baldick (1993), Hopkins (2005), Huckvale (2010), and Groom (2012).

4 The term transculturación was coined by Ortiz in 1940 as a revision of the term "acculturation" introduced in anthropology by J. Malinowski in the 1920s. Ortiz proposed a two (or more) way exchange of cultural influences where his predecessor saw a less powerful culture assimilating into a more powerful one. See Ortiz ([1940] 1987).

${ }^{5}$ The connection between Caliban and the figure of the cannibal was most notoriously established by Fernández Retamar (1973).
} 
The original conceptualization of a tropical gothic has been traced to a conversation between Colombian writer Álvaro Mutis and surrealist filmmaker Luis Buñuel on the (im)possibility of translating the English gothic to the exuberance of the tropics (Mayolo, 2002; 2008; Eljaiek-Rodríguez, 2010; pp. 168-87). Mutis' La mansión de Araucaíma (1973), a novella about a young woman sacrificed in an old colonial hacienda in the Valle del Cauca region in the Southwest of Colombia, first hinted at the term "gótico tropical" from its subtitle: Relato gótico de tierra caliente (a gothic tale from the tropical lowlands). Although Mutis may have been the first to play with this idea of a Gothic in the tropics, it was Mayolo who coined the term and its use in relation to the Grupo's production when he decided to film a homonymous adaptation of the novel (Mayolo, Ospina \& Mayolo, 1986). The aesthetic origin and intent of this gesture was later summarized by Mayolo:

We wanted to make independent, low-budget cinema. Hopefully horror films. We wanted to demystify the horrors of violence and of misery [...,] to create an allegory for a reality that was thorny and razor-sharp. We wanted films shot in the periphery, with only a few characters. Fantasy films where feudal lords consumed and sucked the blood of their workers, where incest was an instrument of power that devoured both perpetrators and victims. [...] We were headed for a genre we ignored. (Mayolo, 2008, p. 91) ${ }^{6}$

Even before this christening of sorts, Mayolo's and Ospina's feature-length films Carne de tu carne ([Flesh of your Flesh] FOCINE \& Mayolo, 1983) and Pura sangre ([Pure Blood] Producciones \& FOCINE \& Ospina, 1982) had introduced gothic characters set in the colonial haciendas and penthouses of contemporary Cali. ${ }^{7}$ The aesthetic concept had already been present in the precocious short stories by Caicedo that were the base for the scripts of both of these films (Berdet, 2016; Suárez, 2010), and vampires, zombies, incest, and cannibalism had in effect appeared in many of his literary texts featuring the Latin American legacy of slavery and colonialism as a backdrop. Due in great part to Caicedo, today the Grupo's tropical gothic has come to denote an aesthetic

\footnotetext{
${ }^{6}$ This and all translations within this article are mine, unless specified otherwise.

${ }^{7}$ The concept, however, eluded readings of the films until much later, as Flórez and Zuluaga remind us:

"The political horizon of 'gótico tropical' is seen today, a prudent distance away from its origins and thanks to the analyses by Felipe Gómez, Juana Suárez, Paulo Antonio Paranaguá and Geoffrey Kantaris [...], as the possibility of inserting local narratives inside these two powerful imaginative matrixes: gothic and tropics" (2015, p. 78).
} 
with a powerful critical function, characterized by the transculturation of elements from modern and colonial realms, baroque in its alternate use of excess, ornamentation, and space; and by its practice of pastiche or appropriation, among others. In the same vein as what Lidia Santos has called "kitsch tropical" (2001), and a precursor for what Latin American art historians have identified as the Ultra Baroque (Labelle, 2001), the Grupo's gótico tropical may best be seen as a hybrid method of resistance created in response to coloniality. Its aesthetics postulate a dark reality both urban and violent, yet humorous, in which youth are protagonists as agents and victims of violence.

The gothic monster's revival in this scenario is intrinsically linked to the powerful influence on the Grupo of gothic literary and cinematic tropes. Caicedo's fascination for the short horror stories by Edgar Allan Poe (which he read in a translation by Argentine writer Julio Cortázar that he underlined profusely), and for Robert Bloch's "respectful" treatment of vampires, witches, and werewolves, was documented in the reading log he kept (published by Editorial Norma as El libro negro ([The Black Book] Caicedo Estela, 2008). His interest in the work of Cyril Connolly and H.P. Lovecraft has also been noted by critics and commentators, as has been the case with directors of Hollywood B-series vampire and horror films, especially those of Roger Corman - whom Caicedo sought out in Los Angeles with the intention of selling him a couple of original film scripts (Gómez, 2004). It should be noted that this fascination for gothic and neo-gothic horror takes place within a local sociopolitical context in which Grupo members grow up with the daily gruesome scenes of the unacknowledged civil war known as La Violencia, ${ }^{8}$ which struck their Southwest Pacific region of Colombia ruthlessly. The Grupo's tropical monsters are thus also engendered in constellations they create by stitching together "global" gothic tropes with local narratives and representations. These are the sites where they see both the underlying haunts of a structural violence rooted in socioeconomic, political, racial, and sexual oppression left behind by the tropical sugar plantation economy, and their links to the present of capitalist production.

Many of Caicedo's characters in the short stories are embodiments of, or share characteristics in common with, gothic monsters. ${ }^{9}$ Some of them are literal, literary, or cinematic displacements into the tropical space that emphasize the role of popular

\footnotetext{
8 "La Violencia," literally "The Violence," is generally understood as a period between aproximately the 1940 s and 1960s characterized by the bloody confrontation between the conservador and liberal political parties which left 200,000 - 300,000 dead, forcefully displaced two million people from their lands, and generated a radical transformation of the Colombian social landscape. See Alape (1999) and Galvis and Donadío (2002).

9 For a discussion and analysis of the Gothic monster centering on its characteristic excess, see Halberstam (1995).
} 
culture in this transcultural process. For instance, Caicedo's protagonist in one of the micro-stories that comprise "Destinitos fatales" ([Fatal Destinies] 1988, pp. 131-2) ritually and voraciously attends all the vampire movies in a film cycle; by the end, his gaze will have revealed him as "The Count" himself, leaving us to our own conclusions about the progressive reduction in the numbers attending the films. ${ }^{10}$

Scenes like the above, in which the monster has been transported to the tropics and enters into contact with its reality, can have an allegoric function within the tropical gothic - but they can also adopt a more direct and confrontational stance, even if they often abandon the monster's literal and literary likeness. The self-proclaimed "vampires of poverty" in Ospina and Mayolo's short "mockumentary" film Agarrando pueblo ([The Vampires of Poverty] SATUPLE, Mayolo \& Ospina, [1978] 2010), for instance, provide an opportunity to speak of socioeconomic and cultural parasitism and exploitation inherent in documentary-making. ${ }^{11}$ These characters will scan the streets of Bogotá and Cali with their cameras in pursuit of images of abjection they want to record in order to export them for European producers interested in real "Third-World" documentaries for their local audiences. With a brilliant use of black humor and the concept of the film within the film, a silent, B/W camera stalks the filmmakers, allowing audiences to document the "vampire's" itinerary as they induce, capture, and recount color images of beggars, prostitutes, homeless children, and a whole checklist of marginal urban characters that must be included in their production, while offering these characters little or nothing in return. The short film, which stands remarkably current today, is a biting commentary directed against the vices of "social" and "testimonial" cinema and more specifically against documentary models bent on exploiting and exporting "third world suffering" for European TV stations and festivals, which Ospina and Mayolo label as pornomiseria, or "poverty-porn" (Cruz Carvajal, 1999, p. 281).

Although the vampires here are not overtly linked in their appearance to the Dracula stereotype, these filmmakers are equated to bloodsuckers who feed off the sweat, misery, and lives of subaltern, marginal subjects, as indicated in the film's subtitle. In this sense, the vamping process in Agarrando pueblo is what Alberto Moreiras so poignantly characterizes as "the production of abjection where the producing agency [...] retains an aura that has been literally sucked off the testimonial subject, now abjected" (1996, p. 203). In other words, "a certain originary and founding outcasting

\footnotetext{
${ }^{10}$ See Eljaiek-Rodríguez (2018, pp. 104-5) for a similar reading of this same text that emphasizes how the count is adapted to the local context while remaining recognizable to readers.

${ }^{11}$ For a more thorough analysis of the tropical gothic elements in this film, see Gómez Gutiérrez (2007, pp. 126-7).
} 
whose most concrete task is to produce empowerment, but whose most precise discursive result is the constitution, or [...] the repetition of a realm of social unlivability," in which "[the] other is always suffering from a certain inability to speak" (p. 201, p. 210). Thus, Ospina and Mayolo's film allows us to recognize how hegemonic tropicalization operates with the film made by the Vampires of Poverty. But that recognition comes thanks to the reverse tropicalization, a tropicalization from below or from the margins, effected by the second camera and other argumentative and technical feats, as discussed below.

An important question raised by the end of this film is whether subaltern characters exploited by vampires may or can speak. In one of the most memorable sequences, the fictional filmmakers receive an interpellation from the true owner of a ramshackle cottage which has been occupied by the whole crew of directors, cameramen, and paid actors in order to shoot the conclusion for their documentary. After confronting the crew, interrupting the shoot, and eluding the filmmakers' and the producer's efforts to subdue him using first the police and then bribery, this Caliban-type chases everyone off his property with a machete, and stands in front of the B/W camera as he unwinds the roll of color film, reviewing and parodying the predictable, superficial nature of the "documentary." He finally assumes the role of the filmmaker by ordering the B/W camera to "cut," but then pauses, as if stepping out of his role and back into his natural self, looks straight at the lens and asks: “¿Quedó bien?" ("Did it come out right?"). The film thus gains a self-destructive ending coherent with its counter-cinematographic principles (Cruz Carvajal, 1999, p. 282). Such a character will inevitably share with Shakespeare's Caliban the deterritorializing appropriation of the language (and thus the role) of the colonizer/director. By hijacking the film, reclaiming his own identity and territory, and adopting the part and the language of the director, the rebellious character positions himself as a Caliban-type alternative springing forth from below to tropicalize vampirisms that act from above against subjects like him (Gómez, 2004a; 2004b; Gómez Gutiérrez, 2007).

Gothic monstrosity is furthermore developed in Ospina and Mayolo's feature-length films more explicitly in connection with historical narratives of socioeconomic and sociopolitical violence in Colombia, and specifically with the period of La Violencia in their region. The gothic is tropicalized here to incorporate complex aspects of local histories and examples of traditional and urban storytelling such as the legend of $L a$ Madremonte (Mother of the forest), the news story/urban legend of a serial child abuser, the "Monstruo de los Mangones" (Monster of the Paddocks), or the representation of 
individual local elites as vampires. ${ }^{12}$ Vampirism in Ospina's Pura sangre (1982), for example, functions as a well-oiled machine: the decrepit, aristocratic owner of a sugar plantation in Cali is dying from a rare illness; in order for him-and the exploitative economic system he represents-to survive, a foreign English-speaking doctor will prescribe daily transfusions of blood extracted from young, non-black, males. ${ }^{13}$ In the different, yet related setting of Mayolo's film Carne de tu carne (1983), teenaged halfsiblings are presented as the allegorical offspring of the elite conservador and liberal political parties. After having incestuous sexual relations, these protagonists develop a taste for human flesh and blood, while their appearance also morphs into the realm of the zombie. In order to clear any ambiguity about its political intentions, the plot is deliberately set during the military regime dictatorship of Gustavo Rojas Pinilla (19531957 ) and the subsequent transition into the "Frente Nacional" [National Front, 19581974], a pact through which both political parties alternated power over the subsequent 16 years.

Othered, female, and Afro-Colombian vampires and cannibals also inhabit and move through the spaces of the Grupo's modern tropical city, exhibiting a lustful relationship with blood consumption to depict social group, class, and gender observations on social and political realities of that moment. This is the case for Antígona in Caicedo's Noche sin fortuna ([Fateful Night] [1988] 2002), a character who dismembers and devours willing teenagers fighting for her attention; and of Jimena, who sexually attracts and then also castrates the traumatized narrator of "Los dientes de Caperucita" ([Little Red Riding Hood's Teeth] 1988, pp. 106-19). In another one of Caicedo's micro-stories, Afro-Colombian passengers direct starved looks at a public employee who discovers, albeit too late, the unusual and disturbing fact that the bus he routinely rides for his lunch break isn't halting at the designated stops (1988, pp. 132). While many of these images will strike current readers as sexist and racist, in Caicedo's texts they often act as markers of unresolved social anxiety related to difference and excess, much in consonance with Halberstam's (1995) observations on representations of female

\footnotetext{
12 The Madremonte is a mythical creature protective of nature and the forest animals and unforgiving when humans enter their domains to alter or destroy them. For more on these types of monstrous representations and their connection to socioeconomic exploitation in the region see Taussig (1980).

${ }^{13}$ The script for this film (which was dedicated to Caicedo by Ospina) was based on an unfinished story that Caicedo wrote. See Esferapública (2008). Carne de tu carne was created by Mayolo based on Caicedo's unpublished adaptation of Henry James' The Turn of the Screw. See Mayolo, 2002 (p. 139). For analyses of these two films focusing on the spectral and tropical gothic elements, see for instance Gómez Gutiérrez (2007; 2012); O’Bryen (2008, pp. 145-156); Suárez (2010, pp. 61-66); EljaiekRodríguez (2012; 2018); and Flórez \& Zuluaga (2015). For an excellent analysis of the use of horror film conventions and their connections with La Violencia in Mayolo's film see Martínez (2009).
} 
monstrosity. The gothic signals these monstrosities in relation to how femininity, race, or unbound sexuality is threatening to male characters. As a result, they are transformed into external others who cannot be imagined as part of the community. As Persephone Braham reminds us when speaking of the telluric novel, "Cannibals and Amazons converge as the toothed vagina [...] as metaphors for identifiable discursive currents such as barbarism" $(2015$, p. 55$)$. If "the central theme of the gothic is violence against women, whether threatened or real" (Braham, 2015, p. 157), the principal task of the hero will be, like in typical American foundation myths, "the destruction, or at least the de-fanging, of the toothed-vagina [...], neutralization that must take place to allow for the vigorous procreative activity requisite to founding a nation" $(2015$, p. 56). In Caicedo's tropicalization of this convention, however, othered characters feed from this outcasting, resulting in an empowerment through the fascination they awaken.

\section{Legacies Beyond the Tropical Gothic}

The development of a tropical gothic to highlight and critically address issues of racial and sexual discrimination, socioeconomic violence, and political corruption is a fundamental element that the Grupo hands down as a legacy to their successors within Latin American literature and cinema. Colombian filmmakers, including Oscar Campo, Jorge Navas, Rubén Mendoza, Oscar Ruiz Navia, Iván Wild, David Flórez, and Simón Mesa, among others, have explicitly referenced and highlighted this legacy in Mayolo's and Ospina's films (Flórez \& Zuluaga, 2015). The ways in which the Grupo tropicalizes the gothic also helps define creative and aesthetic alternatives in stark contrast to coeval literary and cinematic currents omnipresent in the 1960 s and 70 s such as magical realism. In what follows I turn to a deeper consideration of Caicedo's literary writings, to provide a better understanding of the Grupo's interests beyond and complimentary to their tropical gothic aesthetics.

At a time when Gabriel García Márquez and other writers of the Latin American Boom had already established the groundwork for magical realism to become the literary and artistic canon that would define much of what was publishable by writers or filmmakers in the region, Caicedo and the Grupo chose to take a different path. The unconventionality of Caicedo's writing style and motifs in relation to those developed by García Márquez in novels like One Hundred Years of Solitude (1967) effectively locates his writings on the flip side of magical realism, and within the boundaries of eccentricity that Ángel Rama (1985) called "los raros" and Noé Jitrik (1996) the "atípicos". Where magical realism regularly opts for mythical, and allegorical grand récits set in premodern or rural sceneries, in Caicedo the post-national urban youth experience created 
by popular culture and mass media (e.g. the film and music industries) is erected as an essential ingredient and privileged locus of enunciation. His insistence on locating characters in an urban, countercultural, and youthful scenario defined by elements of popular culture such as film, music, or drugs is precisely what attracts writers of the more recent McCondo generation, who have designated Caicedo as their direct literary -and cinematic-ancestor (Fuguet, 2001; 2009). ${ }^{14}$

As a whole, the Grupo's work pioneers the representation of the modern tropical city as a nodal point for the construction/destruction of youth. A panoramic look at Caicedo's short stories can give readers a feel for the centrality of this element: a large portion of them are set in violent, exclusionary, and even sordid urban spaces. Ruined characters who are not only young, but also ill, lonely, and victims of necessary and/or voluntary reclusion narrate many of the short stories written by Caicedo at the time. This is the case of the narrator of "Por eso yo regreso a mi ciudad" ([Why I Return to My City] [1969] 1988, p. 33-5), who devotes his time to observing passersby from behind an obstructed window. In other instances, the city outside is explored by the motion and dérive (Debord, 1981) of mostly mid-to-upper class adolescents to reveal invisible borders formed along the lines of taste and other social markers relating to their access to foreign or higher-class products for consumption. For example, the narrator of "Infección" ([Infection] (1966) 1988, pp. 29-32), a brief text written by a 15-year-old Caicedo, surveys the city while creating a map of his hateful feelings toward it and its inhabitants in a tone suffused with adolescent angst, ennui, and melancholy. Others are moved to explore the vacuum and loneliness of the nocturnal city as in "Vacío" ([Vacuum] [1969] 1988, 36-7), or apply themselves to mapping the sites of consumption and the spaces colonized by transnational commerce. On the other hand, the three short stories in Angelitos empantanados o historias para jovencitos ([Muddy Little Angels or Stories for Young Folks] [1977] 1997a) portray upper-class teenagers who decide to cross those invisible boundaries into the impoverished barrios of the South of the city in pursuit of marginality. The deeper they walk into worlds corrupted by violence and prostitution, the grimmer their situations - naïve, even laughable at first glance seem to get, leading to inevitable episodes of class warfare. In all of these cases the enclosed spaces, the darkened atmosphere, and the fears produced by changes in the sociopolitical and economic realms inscribe the city and its youth in an aesthetics of the gothic.

\footnotetext{
${ }^{14}$ Caicedo's exploration and questioning of heteronormative representations of sexuality, was at the time of publication perhaps as innovative as these other elements, though to date this to remains the aspect of his writing least addressed by critics. My initial contributions to the analysis of these elements can be found in Gómez Gutiérrez (2007; 2011).
} 
Along those same lines, "El atravesado" ([The III-tempered One] [1975] 1997b) may be the text in which Caicedo most vehemently links the modern city with youths' efforts to leave behind a testimony of their self-destructive engagement with it. The deeply oral first-person narrative of Héctor Piedrahita Lovecraft shows us the process through which he joined and established a place for himself within local juvenile gangs. This text is likewise an exploration of the influence of music and film on the configuration of youth subjectivity, with the narration, set in the golden age of the street fighter, constructing a nostalgic view of the 1950s and 1960s through references to films like Rebel Without a Cause and The Wild One, and music hits like "Rock Around the Clock." It also reveals a city in the process of being rapidly colonized by transnational capitalist businesses and corporations, and ruled by the repressive regimes of adulthood incarnated by teachers, rectors, and police officers. El atravesado is framed by the social and political decomposition effected both by the developmental focus of new economic policies brought by Kennedy's Alliance for Progress, ${ }^{15}$ and the assassinations and forced displacements that are the products of La Violencia. Piedrahita Lovecraft's story memorializes recent events while also recreating an atmosphere in which tensions are ripe and the city has foreclosed on the possibility of being known or owned by its youth.

Through the passionate and anecdotal, yet humorous and often naïve narration of the teenager, and through the violent and oppressive urban environment in which it unfolds, Caicedo attempts to challenge "official" adult accounts of this history, to reveal their lies and concealed truths. He does this from outside the canonic domain of magical realism, struggling to document what Duchesne Winter labels the "transformations of contemporary subjectivity" (2009, p. 9), many of which have resulted from interactions among youth, the urban, transnational consumption, and mass media. The latter is a key element employed by Caicedo to construct in his own writing style capable of expressing youth experience in a city that changes rapidly with technology. As Santos has argued, starting in the late 1960s this kind of rhetoric is developed by certain writers and artists in Latin America by inscribing popular culture citations and motifs - extracts from radio, music, and B series films, among others - "in a project to rupture the contemporary aesthetic and political ideology" for which mass culture was considered spurious, immediate, and fragmented (2001, p. 12). The use and transformation of popular culture into "aesthetic artifices" would be directed toward "questioning the realist project contained, for instance, in the narratives of the literary Boom [...], especially those of realismo maravilloso (sic)" (2001, p. 14). This at a time when Latin Americans

\footnotetext{
${ }^{15}$ The Alliance for Progress was a program initiated by U.S. President John F. Kennedy in 1961, aimed at establishing economic cooperation between the U.S. and Latin America.
} 
faced the disappearance of Marxist utopias with the irruption of military dictatorships, ideals of a collective revolution were subsumed under those of the individual revolution preconized by the U.S. counterculture, cities grew rapidly and disproportionately, and mass media consolidated itself as a constitutive part of the urban experience and as a preferred vehicle through which the market aimed to transform citizens into consumers.

Caicedo's interest in cinema is intense, as made clear by the many texts he wrote for local and national newspapers, as well as for the Peruvian film magazine Hablemos de cine and his own Ojo al cine, which came out of the film club he established in Cali in the 1970s. ${ }^{16}$ The incorporation of elements of popular culture in Caicedo's writings is often based upon cinematographic references, as happens with the B-series horror films and with A Clockwork Orange and other sources mentioned above. As a theme, film can likewise be found in stories like "El espectador" ([The Spectator] [1969] 1988, pp. 53-59), in which the city of Cali has been transformed into a Hollywood-style mecca for the film industry; this is also the case in "Los mensajeros" ([The Messengers] [1969] 1988, pp. 126-30), where the narrator, film star Lalita Dos Ríos, offers an apocalyptic and nostalgic view of the city. Films by Hollywood directors Roger Corman, Sam Peckinpah, and Arthur Penn are among those chosen by Caicedo in his search for a language to create an imaginary for the experience of Colombian urban youth, drawing from them the references to violence, humorous camp, and horror (Fernández L'Hoeste, 2009, pp. 245-246).

The kind of intertextuality attempted by Caicedo when quoting and referencing films and filmmakers demonstrates that his interest lies principally in narrating the type of popular culture emerging from North America after the Second World War (Fernández L'Hoeste, 2009 , p. 246), i.e. the present of his contemporaries, over the past, which García Márquez and the Boom writers would have favored (Fuguet, 2009). This may help explain why his writings also touch upon detective fiction and the hardboiled, as in his short stories "Felices amistades" ([Blissful Friendships] [1969] 1988, pp. 60-64) and "En las garras del crimen" ([In the Clutches of Crime] [1975] 1988, pp. 75-87). In this sort of literature Caicedo finds "the fissures in the bourgeois fiber of the middle class" (Fernández L'Hoeste, 2009, p. 246), which lends itself to his purpose of critiquing his society and social class in Cali in the same way in which tropical gothic is used.

\footnotetext{
${ }^{16}$ Most of these texts have been compiled by Ospina and Romero Rey in the volume Ojo al cine (Caicedo Estela, 1999).
} 
Popular music is also favored by Caicedo toward this goal, especially in the novel $i$ Que viva la música! (Long Live Music [1977] 1996), in which music is used as metalanguage to narrate the story of a young countercultural protagonist who decides to explore the middle and lower sectors of society in contemporary Cali while exposing them and the strategies employed by individuals in each group to marginalize or appropriate others. The importance of music in this work is already evident from the title. It is further emphasized by a "discography" included at the end of the novel, compiled by a character called Rosario Wurlitzer who claims having "heard almost all the material mentioned either through open doors, on the radio, or on board buses" ([1977] 1996, p. 191), which highlights both the popular character of this music as well as its currency in the urban experience of the novel.

The narrator, an upper-class young woman, decides to let the music take her on a journey which leads her to the poorest sectors of the city, to eventually end up making a living as a prostitute in the downtown area. Her relationship with music is accepted neither by the conservative views of her social group of origin, nor by an orthodox and militant left which sees foreign and all kinds of popular music as suspect. After having rock music be at the center of her journey throughout the first part of the novel, set in the middle- and upper-class sectors of the city, the narrator falls under the spell of salsa music in the poorer barrios of the South. As she soon discovers, the song lyrics are of utmost importance for this type of music, having an enormous ability to bring together listeners and effect ideological action. The lyrics are, after all, understandable to her, being written and sung in Spanish, and therefore accessible to audiences and bailadores (dancers) who can decode the ideologies contained in them without mediation, in contrast to what happens with rock music in the earlier part of the voyage. This is what the narrator experiences when she enunciates her "total understanding of the moment: that everything in life is lyrics" ([1977] 1996, p. 93), or when she states: "my eyes widened from remembering how much I had understood the Spanishlanguage lyrics, the culture of my land" ([1977] 1996, pp. 100-101). From there she will proceed to sentencing the need to "sabotage Rock to stay alive" ([1977] 1996, p. 104) and acquiring what she deems "structured political conscience" ([1977] 1996, p. 104), ${ }^{17}$ finally embracing salsa as a kind of music more aligned with her cultural and linguistic roots than rock, which she will consider now an import; she will at the same time

${ }^{17}$ Italics in the original. 
distance herself from, and discard, the so-called national music: "I always reject cumbias and pasodobles, and Los Graduados can go to hell” ([1977] 1996, p. 103). ${ }^{18}$

What Caicedo mainly gives us in his novel is the portrait of two very different types of youth subcultures, both sharing the geographic space of the city, but each one enclosed in a clear-cut subdivision sharply delimited by socioeconomic and racial elements. These subdivisions, in turn, have an impact on each of their political choices-the subculture in the North establishes its identity in direct proportion to the level of assimilation, and "accent-free" imitation of an "original" US counterculture,$^{19}$ while the contrasted subculture of salsa incorporates elements of the fusion of races, cultures, and rhythms, making it compatible with a non-whitened reading of the history of Hispanic America since the Spanish invasion, and projecting a view of identity closely related to the concept of transculturation coined by Ortiz ([1940] 1987). Caicedos' narrator seems to take an essentialist view of cultures defined by language and to a certain extent by skin color, and as a result acknowledges neither the hybrid history of Rock and Roll, nor the cultural imperialism of the US-based industrial machine which creates and launches salsa music as a marketable product worldwide (I am thinking here, for instance, of the FANIA music emporium). Problematic as it is, the narration enables audiences to see the role of popular music in the articulation of ideological discourses of hegemony and resistance, and the place of lyrics as messages through which these discourses can be communicated.

One more thing worth mentioning in this novel is the way rhythm permeates Caicedo's writing, constituting a key element in its difference with magical realism and other works belonging to the Latin American canon. The importance of this element has been highlighted by Bernard Cohen, the translator of Caicedo's novel into French. When discussing the difficulties involved in translating the language of this work in its fusion of different kinds of vernacular, marginal Afro-Caribbean languages such as Yoruba, and salsa rhythms and lyrics, he wrote:

While attempting to capture the sidereal musicality of $i$ Que viva la música! I first glimpsed the possibility of translating a text which at first

\footnotetext{
${ }^{18}$ It will seem ironic for the narrator to adopt such a stance toward rock when Caicedo's writing is highly permeated by U.S. popular culture, and it might even be thought to indicate a change when compared to Caicedo's earlier works. However, the end of the novel will disavow this hypothesis, allowing for a more integrative and transcultural idea of culture.

${ }^{19}$ See Bhabha (1984) and Schwarz (1987) on the function of imitation in the formation of Latin American cultures and reflections on social stratifications derived from them.
} 
glance was untranslatable. For the [narrator] Siempreviva [...] music is a vital principle, the foundation of the only harmony that makes or has any sense [...]. It is a universal ecstasy which transcends social norms (the sincerity of salsa in the South of Cali imposes itself upon the rock and roll of the petit bourgeoisie in the North) and stylistic conventions. (Cohen, 2012, p. xi)

In fact, throughout the novel popular music accompanies the narration and thoughts of the protagonist, dictating the narrative rhythm, but also functioning as a means of communication among characters. When extended to incorporate dance (often inseparable from music in the caleño scene), it may in the South substitute the identification documents (IDs) which would have been required to gain entrance at parties in the North. Within the novel, the narrator also uses popular music as a rhetorical device that parallels, complements, or even substitutes the educated, intellectual intertextual citation, effectively creating among the writer, the narrator, and the audience a closed community in which initiation is required to gain access.

In Caicedo's novel as in many of his works there is a register of the unfolding anxiety of groups of Latin American urban youth in search of their own identity as social conflicts stem from and revolve around transnational consumption. Likewise, they record the weakening of both the ideologies on which the idea of the nation has been based, and of the utopias with which the advance of transnational consumerism and imperialism has been challenged. What transpires with full force from these texts is the rapid, even adolescent transformation of the subjectivity of urban youth. These changes are communicated at a thematic and a rhetorical level through a transcultural, tropical contamination and coexistence of the languages of high literary culture and of mass popular culture, including the languages of film, the music industry, and youth subcultures. These aspects are intimately linked to the development of a "tropical gothic" as an identifiable set of qualities, images, and principles with which the Grupo as a whole has sought to narrate experiences pertaining to the modern Latin American city in a particular historical context. The incorporation of urban youth as protagonists and of popular, mass-media culture as a language with which to represent such experience constitute the essence of the contributions that Caicedo, Mayolo, and Ospina have made to Colombian, and Latin American, literature and film. These contributions have been instrumental in the processes undertaken by young writers and filmmakers in Cali and elsewhere in Colombia to define new alternatives beyond the triteness of macondismo as the subsequent, formal imitation of magical realism. 


\section{Acknowledgements}

I am obliged to the two anonymous reviewers for eTropic whose sharp commentaries and attentive reading were essential for the changes made in this article. I'd also like to thank Karen Faulk for her gracious comments and suggestions.

\section{References}

Alape, A. (1999). La paz, la Violencia: testigos de excepción. Bogotá, Colombia: Planeta.

Aparicio, F. R. \& Chávez-Silverman, S. (Eds.). (1997).Tropicalizations: Transcultural representations of latinidad. Hanover, N.H. \& London, U.K.: Dartmouth College, UP of New England.

Baldick, C. (1993). Introduction. In C. Baldick (Ed.), The Oxford book of Gothic Tales (pp. xixxiii). Oxford, UK \& New York, NY: Oxford UP.

Berdet, M. (2016). Gótico tropical y surrealismo. La novela negra de Caliwood. Acta Poética 37(2). Retrieved from http://dx.doi.org/10.19130/iifl.ap.2016.2.733

Beverley, J. (1994). "Writing in Reverse: On the Project of the Latin American Subaltern Studies Group, Subaltern Studies in the Americas, Dispositio XIX (46), 271-88.

Bhabha, H. K. (1984). Of mimicry and man: The ambivalence of colonial discourse. October 28, 125-33.

Braham, Persephone. (2015). From Amazons to Zombies: Monsters in Latin America. Lanham, MD: Bucknell UP.

Caicedo Estela, A. (1988). Destinitos fatales. L. Ospina \& S. Romero Rey (Eds.). Bogotá, Colombia: Oveja Negra.

Caicedo Estela, A. (1996) ¡Que viva la música! (6th ed.) Santafé de Bogotá, Colombia: Plaza y Janés. (Original work published 1977)

Caicedo Estela, A. (1997a). Angelitos empantanados o historias para jovencitos. Santafé de Bogotá: Norma. (Original work published 1977)

Caicedo Estela, A. (1997b). El atravesado. Bogotá, Colombia: Norma. (Original work published 1975)

Caicedo Estela, A. (1999). Ojo al cine. L. Ospina \& S. Romero Rey (Eds.). Santa Fe de Bogotá, Colombia: Norma.

Caicedo Estela, A. (2002). Noche sin fortuna. S. Romero Rey (Ed.). Bogotá, Colombia: Norma. (Original work published 1988).

Caicedo Estela, A. (2008). El libro negro de Andrés Caicedo: La huella de un lector voraz. M. E. Bonilla (Ed.). Bogotá, Colombia: Norma.

Caicedo Estela, A. (2012). Que viva la música! (B. Cohen, Trans.). Paris, France: Belfond. (Original work published 1977)

Caicedo Estela, A. (2013). Traversé par la rage. (Bernard Cohen, Trans.). Paris, France:

Belfond. (Original work published 1975)

Caicedo Estela, A. (2014). Liveforever. (F. Wynne. Trans.). London, U.K.: Penguin Books. (Original work published 1977)

Casanova-Vizcaíno, S., \& Ordiz, I. (Eds.). (2018). Latin American Gothic in Literature and Culture. New York, NY: Routledge. 
Chavarro, S., Arbeláez, R., \& Ospina, L., (Eds.). (2011). Oiga/vea: sonidos e imágenes de Luis Ospina. Cali, Colombia: Universidad del Valle.

Cohen, B. (2012). Cogiéndole el paso a la Siempreviva. In Caicedo Estela, A. ¡Que viva la música! (pp. ix-xvi). Bogotá, Colombia: Alfaguara.

Cruz Carvajal, I. (1999). Agarrando pueblo. In Elena, A. \& Díaz López, M. (Eds.), Tierra en trance: el cine latinoamericano en 100 películas (pp. 279-83). Madrid: Alianza Editorial.

Debord, G. (1981). Theory of the Dérive. In Knabb, K. (Ed. and Trans.), Situationist International: Anthology (pp. 50-4). Berkely, CA: Bureau of Public Secrets.

Díaz-Zambrana, R. \& Tomé, P. (Eds.). (2011). Horrofílmico: Aproximaciones al cine de terror en Latinoamérica y el Caribe. San Juan, Puerto Rico: Isla Negra Editores.

Duchesne Winter, J. (2009). Introducción. In J. Duchesne Winter \& F. Gómez Gutiérrez (Eds.). La estela de Caicedo: Miradas críticas. (pp. 9-13). Pittsburgh, PA: Instituto Internacional de Literatura Iberoamericana \& University of Pittsburgh.

Duchesne Winter, J. \& Gómez Gutiérrez, F. (Eds.). (2009). La estela de Caicedo: Miradas críticas. Pittsburgh, PA: Instituto Internacional de Literatura Iberoamericana \& University of Pittsburgh.

Edwards, J. D. \& Vasconcelos, S. G. T. (2016). Introduction: Tropicalizing Gothic. In Edwards, J. D. \& Vasconcelos, S. G. T. (Eds.). Tropical Gothic in Literature and Culture: The Americas (pp. 1-10). New York, NY: Routledge.

Eljaiek-Rodríguez, G. A. (2010). Selva de Fantasmas. Tropicalización de lo gótico en la literatura y el cine latinoamericanos. (Doctoral Dissertation). Emory University, Atlanta, GA.

Eljaiek Rodríguez, G. A. (2012). Transilvania-Cali-Bogotá: 'Tropicalización' en tres películas de horror colombianas. In R. Díaz-Zambrana \& P. Tomé (Eds.). Horrofílmico. Aproximaciones al cine de terror en Latinoamérica y el Caribe. San Juan, Puerto Rico: Isla Negra Editores.

Eljaiek-Rodríguez, G. A. (2018). Gothic in the Tropics: Transformations of the Gothic in the Colombian Hot Lands. In S. Casanova-Vizcaíno \& I. Ordiz (Eds.). (pp. 96-106). Casanova-Vizcaíno, S., \& Ordiz, I. (Eds.). Latin American Gothic in Literature and Culture. New York, NY: Routledge.

Esferapública. (2008). El rector tiene algo que contar - el diablo y su diabólico opuesto 2/2. Retrieved from https://esferapublica.org/nfblog/el-rector-tiene-algo-que-contar-el-diabloy-su-diabolico-opuesto-22/

Fernández L'Hoeste, H. D. (2009). Delirios de modernidad (y violencia): premonitorios destellos de Hollywood en la obra de Andrés Caicedo. In Duchesne Winter and Gómez Gutiérrez (pp. 245-59).

Fernández Retamar, R. (1973). Calibán: Apuntes sobre la cultura de nuestra América. Buenos Aires: La Pléyade.

Flórez, D. \& Zuluaga, P. A. (2015). Mayolo padre nuestro. Cuadernos de Cine Colombiano, 21, 75-102.

FOCINE (Producer), \& Mayolo, C. (Director). (1983). Carne de tu carne [Motion picture]. Colombia

Fuguet, A. (2001). El hombre que veía demasiado. El Malpensante, 32, 47-49.

Fuguet, A. (2009). Entrevista a Alberto Fuguet (Sobre Andrés Caicedo)/Interviewer C. M. Sotomayor. [Transcript]. Letra Capital. Retrieved from http://carlosmsotomayor.blogspot.com/2009/01/entrevista-alberto-fuguet-sobreandrs.html 
Galvis, S. \& Donadío, A. (2002). El jefe supremo: Rojas Pinilla en La Violencia y en el poder. Medellín, Colombia: Hombre Nuevo.

Gómez, F. (2004a). Misterio regio: Contracultura y el cadáver de Caicedo. (Unpublished doctoral dissertation). University of Michigan, Ann Arbor, MI.

Gómez, F. (2004b). Trópicos góticos: vampirismos transculturados por el Grupo de Cali. Tropos XXX, 42-70.

Gómez Gutiérrez, F. (2007). Caníbales por Cali van: Andrés Caicedo y el gótico tropical, IKALA: Revista de Lenguaje y Cultura, 11(17), 121-42.

Gómez Gutiérrez, F. (2011). Andrés Caicedo y la sexualidad de los angelitos. Arcadia, 69. Retrieved from: https://www.revistaarcadia.com/libros/articulo/la-sexualidad-de-losangelitos/25435.

Gómez Gutiérrez, F. (2012). La violencia y su sombra. Asomos al género del horror en el cine colombiano: Vallejo, Mayolo, Ospina. In Díaz-Zambrana, R. \& Tomé, P. (Eds.). Horrofílmico. Aproximaciones al cine de terror en Latinoamérica y el Caribe (pp. 281299). San Juan, Puerto Rico: Isla Negra Editores.

Gómez Gutiérrez, F. (2014). Andrés Caicedo: "Rareza, belleza y sabor", o un pozo que no quiso llamarse Macondo. In González, C. (Ed.). Fuera del canon: Escrituras excéntricas de América Latina (pp. 223-250). Pittsburgh, PA: Instituto Internacional de Literatura Iberoamericana.

Gómez Gutiérrez, F. \& De la Vega-Hurtado, M. (2009). Documentary Third Cinema in Colombia: The Case of Luis Ospina. In Ekotto, F. \& Koh, A. (Eds.). Rethinking Third Cinema: The Role of Anti-Colonial Media and Aesthetics in Postmodernity (pp. 53-80). Berlin: Lit Berlin.

Groom, N. (2012). The Gothic: A very short introduction. Oxford, U.K: Oxford University Press.

Gutiérrez-Mouat, R. (2005). La retórica de la monstruosidad en la narrativa latinoamericana contemporánea: Un panorama crítico. Hispamérica 34(101), 3-13. Retrieved from http://www.jstor.org/stable/20540634

Halberstam, J. (1995). Skin shows: Gothic horror and the technology of monsters. Durham, NC: Duke UP.

Hopkins, L. (2005). Screening the Gothic. Austin, TX: University of Texas Press.

Huckvale, D. (2010). Touchstones of gothic horror: A film genealogy of eleven motifs and images. Jefferson, N.C: McFarland \& Co.

Jitrik, N. (1996). Prólogo. In Jitrik, N. (Ed.). Atípicos en la literatura latinoamericana (pp. 11-15). Buenos Aires: Universidad de Buenos Aires.

Labelle, C. (2001). Ultra Baroque (Review). Frieze, 56, https://frieze.com/article/ultra-baroque

Márquez, G. G. (1967). One Hundred Years of Solitude [Cien años de soledad]. Buenos Aires: Editorial Sudamericana

Martínez, M. I. (2009). Incesto, vampiros y animales: la Violencia colombiana en Carne de tu carne de Carlos Mayolo. Revista de Estudios Colombianos, 33-34, 63-77.

Mayolo, C. (2002). Mamá, ¿Qué hago?: Vida secreta de un director de cine. Bogotá, Colombia: Oveja Negra.

Mayolo, C. (2008). La vida de mi cine y mi televisión. Colección Dorada. Interés General. Bogotá, Colombia: Villegas.

Mayolo, C., and Ospina, L. (Producers) \& Mayolo, C. (Director). (1986). La mansión de Araucaíma [Motion picture]. Colombia: Focine. 
Moreiras, A. (1996). The aura of testimonio. In Gugelberger, G. M. (Ed.). The Real Thing: Testimonial Discourse and Latin America (pp. 192-224). Durham, NC: Duke UP.

Mutis, Á. (1973). La mansión de Araucaima: Relato gótico de tierra caliente. Buenos Aires: Edit. Sudamericana.

Negroni, M. (2009). Galería fantástica. México: Siglo XXI.

O'Bryen, R. (2008). Literature, Testimony and Cinema in Contemporary Colombian Culture: Spectres of La Violencia. Woodbridge, U.K.: Tamesis.

Ortiz, F. (1987). Contrapunteo cubano del tabaco y el azúcar. Caracas: Biblioteca Ayacucho. (Original work published 1940)

Paranaguá, P.A. (1996). Colombia y Bolivia. In Costa, J. et. al. Historia general del cine. Vol X. Madrid: Cátedra.

Planells, A. (1988). El realismo mágico hispanoamericano ante la crítica. Chasqui 17(1), 9-23.

Pratt, M. L. (1991). "Arts of the Contact Zone." Profession 91, 33-40.

Producciones Luis Ospina \& Focine (Producers), \& Ospina, L. (Director). (1982). Pura sangre [Motion picture]. Colombia: Film.

Rama, Á. (1985). El boom en perspectiva. In Rama, Á. La crítica de la cultura en América Latina (pp. 266-306). Caracas: Biblioteca Ayacucho.

Santos, L. (2001). Kitsch tropical: Los medios en la literatura y el arte de América Latina. Madrid: Iberoamericana - Vervuert.

SATUPLE (Producer), \& Mayolo, C. (Director), \& Ospina, L. (Director). (1978). Agarrando pueblo (Los vampiros de la miseria) [Motion Picture]. Luis Ospina, 2010. DVD.

Schwarz, R. (1987). Que horas são? Sao Paulo, Brazil: Companhia das Letras.

Suárez, J. (2009). Disyuntivas visuales: del experimento al gótico tropical. In Suárez, J. Cinembargo Colombia. Ensayos críticos sobre cine y cultura. Cali: Universidad del Valle.

Suárez, J. (2010). Sitios de contienda: producción cultural colombiana y el discurso de la violencia. Madrid: Iberoamericana Vervuert.

Suárez, J. (2014a). De casas y haciendas azucareras en el gótico tropical. In G. Hernández Samaniego \& E. Ortiga Pareja (Eds.). Carlos Mayolo. Un intenso cine de autor (pp. 6182). México: Universidad Nacional Autónoma de México.

Suárez, J. (2014b). Tropical Gothic: Cinematic Dislocations of the Caribbean Imaginary in South West Colombia. Studies in Gothic Fiction, 3 (2), 24-37.

Taussig, M. T. (1980). The devil and commodity fetishism in South America. Chapel Hill: University of North Carolina Press. 